\title{
TEXTUL DIALECTAL CA SURSĂ PENTRU CERCETAREA ȘTIINȚIFICĂ
}

\author{
Liliana POPOVSCHI \\ Institutul de Filologie Română „Bogdan Petriceicu-Hasdeu” (Chișinău)
}

ORCID: https://orcid.org/0000-0002-7032-142X

\begin{abstract}
Rezumat: Textul dialectal prezintă o importanță deosebită pentru cercetările din diferite domenii ale științei: dialectologie și alte discipline lingvistice, istorie, etnografie, folcloristică, psihologie, discipline de graniță, cum ar fi etnolingvistica, sociolingvistica, psiholingvistica, servind drept sursă documentară.

Cuvinte-cheie: text(e) dialectal(e), valoare documentară, sursă, cercetare științifică, domenii ale științei.

Abstract: The dialectal text is of particular importance for research in different fields of science: dialectology and other linguistic disciplines, history, ethnography, folklore studies, psychology, interdisciplinary fields such as ethnolinguistics, sociolinguistics, psycholinguistics, serving as a documentary source.
\end{abstract}

Keywords: dialectal text(s), documentary value, source, scientific research, fields of science.

Articolul de față încearcă să atragă atenția asupra valorii documentare a textului dialectal ca produs al investigațiilor dialectologice de teren, evidențiind unele posibilități de abordare a acestuia în activitatea de cercetare științifică.

Textul dialectal este o modalitate de colectare a materialului dialectal, utilizată de multă vreme și cu perseverențăîn dialectologia românească, deoarece oferă rezultate însemnate, unele imposibil de obținut cu ajutorul altor mijloace. Tezaurizat în arhive fonogramice sau publicat în culegeri, materialul înregistrat, extrem de bogat în informații de natură diferită, se relevă drept sursă documentară pentru cei interesați de studiul limbii, în general, al variantelor sale teritoriale, în special, sau al diverselor aspecte ale vieții la care se referă, direct sau indirect, purtătorii graiurilor românești în timpul conversației cu anchetatorul. Așadar, din punctul de vedere al utilității sale ca instrument de lucru, textul dialectal se remarcă prin importanța deosebită pe care o prezintă pentru cercetările din domeniul lingvisticii, precum și pentru cele din alte ramuri ale științelor socio-umane, inclusiv pentru disciplinele de graniță, cu caracter interdisciplinar. Astfel se explică de ce „culegerea și publicarea de texte dialectale, paralel cu realizarea atlaselor 
lingvistice, s-a impus ca o preocupare specifică a dialectologiei românești” (Hreapcă, 1975, p. 137).

Se știe că, odată cu adunarea materialului pentru Atlasul lingvistic român (ALR), în fiecare localitate au fost înregistrate și texte dialectale, care aveau menirea să completeze datele obținute în baza chestionarului, permițând studierea, în mai mare măsură, a fenomenelor de sintaxă, fonetică sintactică și stilistică, iar în 1943, ca supliment la ALR II, apare volumul de Texte dialectale, culese de Emil Petrovici (Petrovici, 1943). Acest fapt a constituit o inovație ce a sporit originalitatea și valoarea documentară a atlasului în raport cu lucrările similare din alte țări europene. (Din păcate, volumul, cuprinzând textele adunate de Sever Pop, a fost distrus în timpul unui incendiu survenit la tipografie (Pop, 1950, p. 710)). În acest context, merită subliniat faptul că, prin proiectul ALR, Sextil Pușcariu a aprofundat cercetările privind dialectul dacoromân, inițiate de dascălul său, Gustav Weigand - întâiul lingvist care a străbătut întreg spațiul în care se vorbește acest dialect, înregistrând material pe care l-a valorificat în studii, dedicate fiecărei zone anchetate, și în Atlasul lingvistic al teritoriului dacoromân (WLAD), apărut la Leipzig în 1909. Materialul cuprinde atât particularităţi dialectale, culese în baza chestionarului, cât și creații folclorice, pe care lingvistul german le anexează la studiile publicate, în cea mai mare parte, în Anuarul Institutului de limba română de pe lângă Universitatea din Leipzig și care formează corp comun cu hărțile Atlasului (Arvinte, 1992-1993, p. 32).

Culegerea de texte dialectale a continuat odată cu demararea anchetelor pentru elaborarea Noului atlas lingvistic român (NALR) cu același scop: completarea materialului dialectal cu date referitoare, în special, la stilul vorbit, dar cu o metodă îmbunătățită în ceea ce privește tipologia textelor („tematice” și „libere”), numărul de informatori din fiecare localitate, criteriile de selectare a informatorilor etc. (TD-Olt., p. XVII-XX). Chiar dacă înregistrările s-au realizat în cadrul unui program paralel: Arhiva fonogramică a limbii române (AFLR), ele sunt direct legate de proiectul NALR, datorită rețelei comune de localități anchetate.

În spiritul tradiției românești, în timpul anchetei pentru elaborarea Atlasului lingvistic moldovenesc (ALM) din anii 1957-1965, dialectologii de la Chișinău au înregistrat pe benzi de magnetofon peste 3000 de texte, în vederea constituirii unei arhive fonogramice. Aproape jumătate din textele culese au fost publicate în 3 volume a câte 2 părți fiecare, care poartă subtitlul Supliment la Atlasul lingvistic moldovenesc (TD-Mold.).

Texte au fost adunate și în cadrul unor programe aparte, precum cel din anii 1965-1968 în zona „Porțile de Fier” (Cohuț, Vulpe, 1973, p. XI-XII) sau 
programul de cercetare a graiurilor românești vorbite în afara granițelor României, inițiat de dialectologii bucureșteni în ultimul deceniu al secolului trecut și realizat de echipe mixte de cercetători de la Academia Română și de la institutele de profil din țările vecine, materialul rezultat din expedițiile efectuate fiind tezaurizat în AFLR și publicat în câteva volume (Marin, Mărgărit, Neagoe, Pavel, 2016, p. 25).

Concepute ca părți componente ale aceleiași lucrări (conform viziunii Pușcariu - Petrovici - Pop) sau nu, atlasele lingvistice și textele dialectale constituie forme complementare de prezentare a varietăților dialectale ale limbii, fiecare cu propriile sale atuuri: „dacă primele evidențiază aria de răspândire a fenomenului, textele au calitatea de a scoate în evidență varietatea contextelor de utilizare, complexitatea acestora, frecvența, dar și de a aduce noi atestări în privința extinderii geografice a acestei caracteristici” (Marin, 2017, p. 250). Ca modalitate de înregistrare a materialului dialectal, textul dialectal, prin autenticitatea și spontaneitatea formulării pe care le asigură, permite o apropiere mai eficientă de mecanismele vorbirii decât chestionarele utilizate în timpul anchetelor pentru atlasele lingvistice (Marin, Mărgărit, Neagoe, Pavel, 2000, p. X; Marin et. al., 2016, p. 27). Hărțile lingvistice fixează „imaginea... nemișcată a graiului din fiecare punct cartografic”, pe când textele dialectale constituie „imagini mișcătoare pe care putem urmări aceleași graiuri în mers, fiecare cu ritmul și mlădierile sale proprii”, sublinia Emil Petrovici în Introducerea la volumul amintit mai sus (Petrovici, 1943, p. VII).

Cert este că, indiferent de perioada când au fost culese (începutul sau sfârșitul secolului al XX-lea), scopul urmărit (completarea datelor din atlasele lingvistice sau pur și simplu surprinderea la o anumită etapă de evoluție a limbii române vorbite la nivel dialectal în anumite zone ale arealului românesc sau în afara lui), forma de prezentare/ conservare (arhiva fonogramică, album de discuri, culegeri publicate), textele dialectale reprezintă sursede o valoare documentară inestimabilă.

Mostrele de vorbire dialectală sunt întâi de toate documente de mare preț pentru lingviști. Extrapolând constatarea lui Gr. Brâncuș cu privire la volumul Texte dialectale. Oltenia, cu siguranță nu vom greși afirmând că întreg tezaurul de texte dialectale adunat până în prezent „satisface cu prisosință cerințele de material faptic ale specialiștilor din aproape toate ramurile lingvisticii românești” (Brâncuş, 1969, p. 185). Oferind posibilitatea examinării multor fenomene fonetice, lexico-semantice, morfologice și sintactice în contexte autentice, firești de manifestare, textele dialectale sunt importante atât pentru disciplinele care se 
ocupă de nivelurile structurale ale limbii (fonetica, lexicologia, gramatica), cât și pentru cele ce studiază varietatea limbii, în sincronie și diacronie (dialectologia, stilistica, sociolingvistica, istoria limbii), iar concluziile cercetărilor pentru care servesc drept material faptic au menirea să umple anumite „goluri” din lingvistica românească și din cea romanică, să precizeze și să completeze principiile de lingvistică generală. La ora actuală, când lingvistica „se concentrează tot mai mult pe aspectele funcționale, care țin de uzul limbii” (Molea, 2016, p. 19), textele dialectale sunt deosebit de utile pentru abordarea unor probleme din sfera de interes a unor direcții și domenii noi de investigație științifică: pragmatica, lingvistica textului/ a discursului, analiza comunicării etc.

Avantajul consultării textelor este acela de a putea urmări faptele de limbă în dinamica discursivă și de a surprinde fenomene ce sunt specifice formei orale de comunicare.

Cât privește latura sonoră a limbii, în afară de faptul că reflectă particularitățile fonetice ale graiului din localitățile anchetate, textele dialectale ne permit să observăm „variațiile fonetice de la un individ la altul sau chiar la același individ în momente diferite" (Brâncuș, 1969, p. 185):

(1) M-am sculád dè d imináţă, ieri de diminațt, m-am sculát, m-am imbrăcát, m-am spălát, m-am încălțát, am luat mătura, am scuturát pi门_cámịra am măturát, pe urm-am luat vítele, le-am dus pest-ápă, am

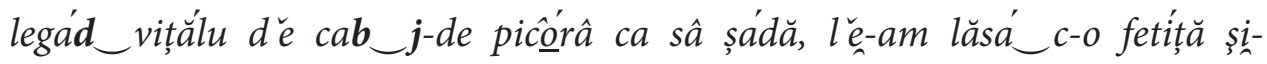

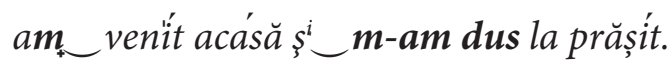

Pe urm-am venḯ $[k] \boldsymbol{m}$-an_duz_dúpă fetiță că s-a pus pe plóuă si-am luad_vítel è acásă și-am plècát la víie dup-amniáz. (TD-Olt., p. 178)

(2) [...] pliví um—pig la grîu, tupa si pliví la grîu, veníi acásă, facuí mîycári şî ma culcái um_pic [...] (Ibidem, p. 195)

Tot în context pot fi identificate accidente fonetice (afereze, apocope, sincope etc.) datorate influenței reciproce dintre sunete sau ritmului mai alert al vorbirii:

(1) cînd_am mîntuít covóru di țăsút/ an _luat șî am slobodî́t/ șî ị-an+

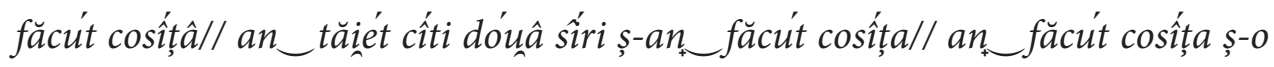
rămás zimatá-dì-arșî́n di uruióc [...]

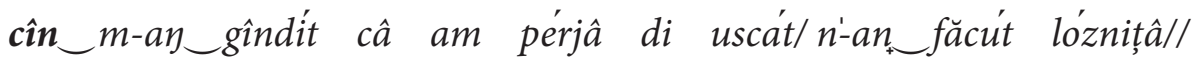
an sapát "o gr"oápâ-n pomînt/ gr"oápa an _sapát-o di-on métru zîmatáti di 
lúngâ șî dị-on arșî́n di adî́ncâ// (TD-Mold. I/1, p. 128-129)

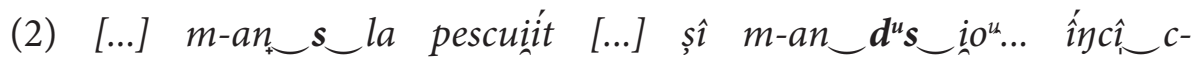

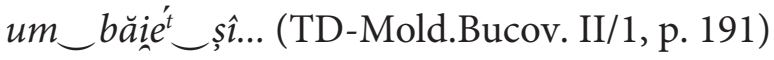

(3) "dómnule stóica"/ ícê "ie cinevá dă la țáră"//

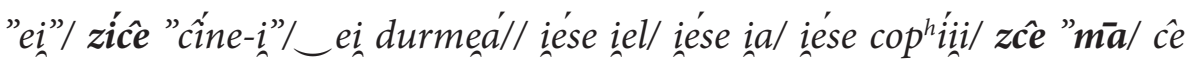

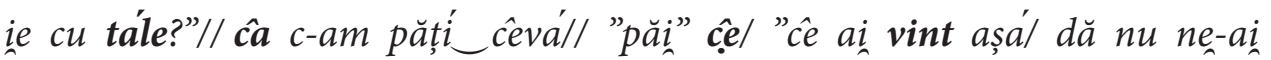
spuz/—nu numic"///(TD-Munt. I, p. 44)

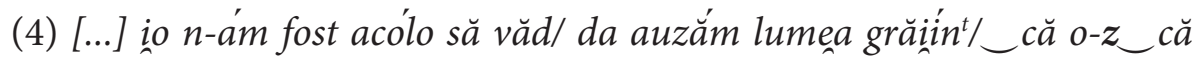
n-o putú_murí// (Marin et al., 2000, p. 403)

Probleme de fonetică sintactică au fost analizate pe baza textelor dialectale culese de E. Petrovici într-un amplu studiu semnat de Marius Sala (Sala, 1955).

Din punct de vedere lexical, textele dialectale pun în evidență bogăția și varietatea terminologică a graiurilor românești - oglindă a modului de viață din satul tradițional și expresie a creativității glotice a purtătorilor de grai popular. Lexicul variantelor regionale ale limbii, care, cum bine se știe, cuprinde câteva categorii de elemente: cuvinte comune pentru graiuri și limba literară, cuvinte cu întrebuințare limitată la un anumit teritoriu, modificări de formă sau de sens ale unor cuvinte de largă circulație, creații lexicale inedite, este înregistrat în mai multe tipuri de lucrări: atlase lingvistice, glosare, dicționare, culegeri de texte. Textelor însă „le revine privilegiul” de a prezenta terminologia referitoare la domenii specifice mediului rural ,în dinamica vorbirii”, în descrieri ale uneltelor și ale operațiilor ce se execută cu acestea, plasate uneori în contexte și mai largi (Dumistrăcel, 2014, p. 131). Astfel, în exemplul (1), citat mai sus, pe care l-am extras din înregistrările efectuate în localitatea Stoicani din raionul Soroca, Republica Moldova, cuvântul cosiță (în forma cosî́ţâ) apare în descrierea procesului de țesere a covorului cu sensul „fire împletite de la capetele covorului".

Textele dialectale completează informația din atlasele lingvistice cu privire la faptele de morfologie. De exemplu, textele înregistrate în Oltenia și în vestul Munteniei ca răspuns la întrebarea „Ce a făcut subiectul ieri și azi” permit precizarea valorilor perfectului simplu și a perfectului compus:

[Ieri] m-ã_sculát d"iminiáța, m-ã_splalát, pẹ̣-órmă m-am îmbracát.

Dúpa se m-am îmbracát, am plecat la sạát. [...] De az d'imináțâ íar la fel'. Mă sculái șî mă spaláí. Plecái inar la sapát, veniíi acásâ (TD-Olt., p. 167). 
Conform unui principiu de adunare a materialului dialectal, formulat de Sextil Pușcariu (Pușcariu, 1938, p. 11), culegerea de texte este necesară îndeosebi pentru studierea fenomenelor de sintaxă, pe care atlasele lingvistice nu le pot fixa. Preocuparea pentru aspectul sintactic al limbii vorbite se numără printre motivațiile proiectelor ulterioare ce urmăreau constituirea diferitor corpusuri de texte dialectale. Pe baza acestora au fost elaborate valoroase monografii și studii,consacrate sintaxei părților de vorbire, sintaxei propoziției, coordonării și subordonării în frază (a se vedea: Dumistrăcel, 1993, p. XXI; Dumistrăcel, 2014, p. 120-122; Purice, Zagaevschi, Ciornîi, 1991, p. 165-166), ceea ce confirmă importanța lor pentru cercetările din domeniul sintaxei.

Principalul „beneficiar” al materialului cules cu ajutorul anchetei de texte (ca și al celui cules pentru atlase) este, bineînțeles, dialectologia, sincronică și diacronică. Abordat din punctul de vedere al variației diatopice a limbii, el face posibilă studierea unui șir de probleme dialectologice. Atestând trăsăturile fonetice, lexicale, morfologice și sintactice ale graiurilor din localitățile anchetate, textele permit precizarea ariilor de răspândire a particularităților dialectale și, în consecință, delimitarea mai exactă a unităților geografice ale limbii, identificarea trăsăturilor care le individualizează și care le apropie, determinarea schimbărilor ce au loc în prezent în graiuri, a influenței reciproce dintre graiuri, a raporturilor dintre limba literară și graiuri, a specificului dezvoltării graiurilor periferice și insulare ale limbii române în comparație cu cele centrale etc. Cercetările de fonetică dialectală, lexicologie dialectală și gramatică dialectală, efectuate pe baza textelor, furnizează rezultate, menite să întregească descrierea unităților teritoriale ale limbii române.

Dinamica graiurilor românești poate fi observată prin compararea particularităţilor dialectale reflectate de textele culese în perioade diferite în aceleași localități (sau în localități învecinate). Pentru a facilita studiile diacronice, dialectologii ieșeni au oferit în volumul I, părțile 1 și a 2-a, din seria NALR. Moldova și Bucovina. Texte dialectale lista localităților pentru care au fost publicate anterior texte dialectale (și folclorice), iar la volumul II, partea 1, au anexat o addendă, care pune la dispoziția cercetătorilor chiar texte dialectale, selectate din izvoare, datând de la începutul secolului al XX-lea (TD-Mold. Bucov. II/1, p. 231-266). Întrucât elemente pentru comparaţia în plan diacronic pot fi extrase de asemenea din atlasele lingvistice, vom remarca și utilitatea corespondențelor cu punctele de anchetă din rețelele WLAD și ALR, oferite de volumele de texte dialectale. Deosebit de edificatoare ar fi comparația cu mostrele de grai românesc, culese în ultimul deceniu al secolului trecut și în 
primul deceniu al secolului al XXI-lea în cadrul programului de cercetare a graiurilor dacoromâne din afara granițelor României, care au cunoscut o evoluție diferită față de restul spațiului românesc.

Având în vedere data la care s-au realizat principalele anchete de texte, cercetările privind diacronia trăsăturilor dialectale ar pune în evidență direcția evoluției graiurilor românești cel puțin pe parcursul unei jumătăți de secol. Pentru unele zone analiza ar putea cuprinde un segment temporal de până la un secol. De exemplu, texte din Boian, regiunea Cernăuți, au fost incluse în lucrarea lui G. Weigand referitoare la graiurile din Basarabia și Bucovina (Weigand, 1904, p. 70), în culegerea lui Emil Petrovici (Petrovici, 1943, p. 169-172), în primul volum publicat la Chișinău (TD-Mold. I/1, p. 49-66) și în lucrarea Graiuri românești din Basarabia, Transnistria, nordul Bucovinei și nordul Maramureșului. Texte dialectale și glosar (Marin et. al., 2000, p. 239-277). Din zona Maramureșului, cercetată sub aspect lingvistic și folcloric la sfârșitul secolului al XIX-lea - începutul secolului al XX-lea de Gustav Weigand (1899, p. 1-85), Tache Papahagi (1925), Alexandru Țiplea (2008) ș. a., pentru același volum dedicat românilor din jurul României au fost selectate patru localități, printre care și Biserica Albă (p. 314-331), de unde a cules majoritatea textelor Alexandru Țiplea și care a fost anchetată și pentru ALM.

Așadar, servind la stabilirea liniei evolutive a fenomenelor de limbă, textele dialectale se dovedesc a fi izvoare valoroase pentru dialectologia diacronică și pentru istoria limbii.

Dat fiind faptul că textele vizate sunt dialectale doar din punctul de vedere al „codului”, iar din punctul de vedere al „canalului” (al modalității de transmitere) este vorba despre texte orale, transcrise fonetic pentru faza publicării (Dumistrăcel, 2003, p. 12-14; Idem, 2014, p. 120), ele oferă o importantă bază documentară pentru studiul oralităţii - obiect al cercetărilor din domenii mai vechi sau mai noi ale științei: stilistica, pragmatica, lingvistica vorbirii, teoria comunicării etc.

Textele dialectale sunt ilustrative, mai cu seamă, pentru varianta rustică a oralităţii nonstandard, ce se caracterizează prin spontaneitate, afectivitate, naturalețe, libertate în alegerea mijloacelor de expresie și ignorarea normelor limbii standard. Ele abundă în fapte de stil, determinate de trăsăturile definitorii ale limbii vorbite, de condițiile specifice de desfașurare a comunicării orale, de intențiile comunicative. Pe de o parte, în texte „stilul vorbit dialectal” apare „în toată complexitatea lui” (Brâncuș, 1969, p. 185), cu întreaga gamă de mărci distinctive la nivel fonetic, lexical, gramatical, discursiv și pragmatic: 
pronunțări regionale, modificări fonetice cauzate de interdependența sunetelor în lanțul vorbirii sau de un debit verbal rapid, accente afective și variații de înălțime a intonației (redate în culegerile publicate $\mathrm{cu}$ ajutorul semnelor de transcriere fonetică a textelor), cuvinte şi expresii populare, augmentative și, mai cu seamă, diminutive, forme gramaticale neliterare, diverse mijloace de exprimare a superlativului, repetiții, interjecții, deictice, topică afectivă, formule de adresare, substantive în vocativ, verbe la imperativ, enunțuri exclamative și interogative, enunțuri incomplete, construcții eliptice, discontinuitate sintactică și alte greșeli de exprimare (anacolutul, dezacordul etc.), subordonate omogene, juxtapunerea propozițiilor simple, utilizarea, pe larg, a conectorilor narativi etc. (Got, 2007, p. 27; Molea, 2016). Pe de altă parte, cercetătorul are posibilitatea să descopere mai multe varietăți stilistice - manifestări ale limbajului oral utilizat în mediul rural, de la cele corelate cu tipurile de texte înregistrate în timpul anchetelor (limbajul popular nonartistic, nuanțat tehnic, ilustrat de textele "tematice”, în general descriptive, și stilul artistic popular, ilustrat de textele „libere”, de regulă narative, relatând evenimente, întâmplări din viața informatorilor sau din istoria satelor) până la modurile individuale de întrebuințare a mijloacelor de expresie, concretizate în texte:

avém noi acoló o valsicâl î̀i búnâ di cî́nipâl/ mai dusém gunói lî rîșt'irám gunoìu/ şî arám// arám gïnişór/ marunțắl/ ii bun pomîntu/ şîn ni dusém sâ samanắm cî́nipâl/ o puném rînduri ca sâ $n$-o strî́ngâ vrăgịli// puném rî́nduri/ fasém cu sápa rînd şî cu mî́na samanám/ rî́nduri puném// an—pus noi rî́ndurli sélial s-o mesticát/ níşti vrăgíi n'-o scurmát-o hăt// ăil/ si_şî mai

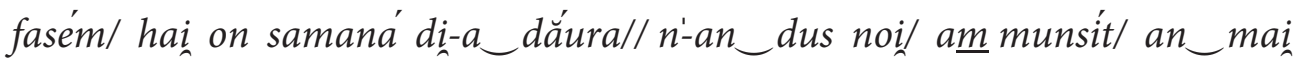
pus iárâ rî́nduri// am samanát noi/ gîndésc/ si şî mai puu/ şî nu víi vrăgí? ?// ăi /

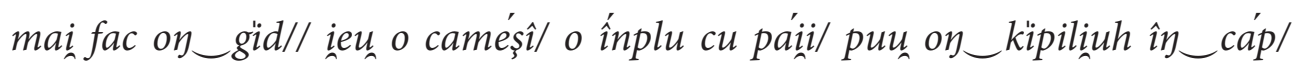
păzăști cî́nipa acoló// n-o scurmát-o vrăg'// ma duc pişsti vo duoáuâ-trii

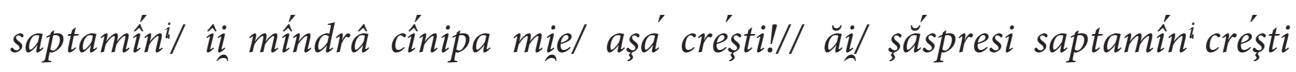

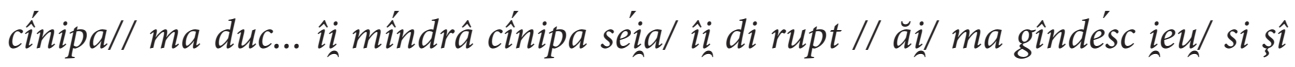
fac?// ş-o alég ori s-o rup aşá// nu/ oi alézi-o// oi alézi ş-oi avé şî samînțâ pí la ánu di samanát// (TD-Mold. I/1, p. 133).

După cum bine se știe, oralitatea se remarcă printr-un grad sporit de expresivitate, redând cu mare precizie și pregnanță gânduri, sentimente, reacții afective și atitudinale, pentru a produce efectul scontat asupra destinatarului, 
iar textele dialectale dezvăluie caracterele ei particulare. Se pot face, deci, observații stilistice asupra expresivității neaoșe și afective, declanșate de emoția spontană, generată, la rândul ei, de „contextul verbal și situațional imediat”, asupra expresivităţii latente a oralităţii, „conținută în elementele ei verbale”, precum și asupra celei deduse din context, „prin care se obțin sensuri metaforice inedite revelatoare de atitudini și stări” (Molea, 2016, p. 67). Cu alte cuvinte, multe texte nu doar etalează expresivitatea implicită, proprie exprimării prin viu grai, ci impresionează prin varietatea mijloacelor expresive ca indiciu al implicării emoționale a povestitorului, ceea ce le conferă, după cum notează unii cercetători (Beltechi, 1974, p. 462), și calități estetice remarcabile.

$\mathrm{Nu}$ sunt lipsite de interes nici schimbările de registru, atestate în vorbirea unor informatori, trecerea de la registrul uzual (dialectal) la registrul „de lux" (literar), în condițiile speciale de comunicare pe care le crează ancheta: prezența anchetatorului ca persoană care aparține altui mediu social, faptul că informatorul face o expunere, înregistrată cu un aparat etc. (Hreapcă, 1975, p. 138). Asemenea situații, au la bază, bineînțeles, un ansamblu de factori extraverbali (psihici, afectivi, intelectuali, sociali) și justa lor interpretare necesită abordări din mai multe puncte de vedere (lingvistic, psiholingvistic, sociolingvistic...).

Ținând cont de faptul că la construirea sensului mesajului oral contribuie atât elementele verbale, cât și cele paraverbale și nonverbale, precum și elementele cadrului situațional în care se desfășoară comunicarea, redactorii culegerilor de texte dialectale au avut grijă să descrie în notele din subsolul paginilor gesturile informatorilor, poziţia corpului, mimica sau diferite alte reacții ale acestora (râs, plâns, oftat), să precizeze persoanele cărora li se adresează, localităţile sau evenimentele la care fac referire. Intonația, pauzele, întreruperile, ezitările, repetările, corectările, marcate prin diverse semne grafice în corpul textului, sunt și ele uneori comentate sau explicate în note. Astfel, întreruperile pot fi cauzate de plâns, oftat, intrarea în încăpere a unei alte persoane, intervențiile persoanelor care asistă la înregistrare sau ale anchetatorului, schimbarea benzii de magnetofon etc. Dialectologul clujean Ion Faiciuc susține, pe bună dreptate, că „relevarea unor astfel de detalii are nu numai o importanță practică (înțelegerea textelor), ci și una teoretică, pentru lingvistica generală, pentru teoria generală a limbajului” (Faiciuc, 1974, p. 145). Informațiile de acest gen sunt utile pentru o abordare a textelor dialectale din perspectiva pragmaticii, în special, pentru a evidenția „capacitatea unei unități lingvistice de a exprima, situațional, mai mult decât datul ei anterior” (Colciar, 
2007, p. 236). Ținem să subliniem că analiza pragmatică a textului dialectal este una din preocupările actuale ale lingvisticii românești, concretizată în lucrări semnate de Liliana Ionescu-Ruxăndoiu, Magdalena Manu Magda, Rozalia Colciar (Dumistrăcel, 2014, p. 122-127). Oglindind mecanismele procesului comunicativ la nivelul limbii române vorbite regional, în strânsă legătură cu contextul situațional, textele dialectale fac posibilă studierea unor probleme specifice acestui domeniu: comportamentul verbal al vorbitorilor, intențiile lor comunicative, strategiile discursive.

Posibilitățile de utilizare a textelor dialectale depășesc cadrul strict lingvistic. Prin conținutul lor, textele dialectale reprezintă surse de informații privind cultura, mentalitatea și psihologia populară, organizarea socială și evoluția comunităților românești, oferind repere importante pentru cercetările de etnografie, folclor, istorie, sociologie, psihologie.

O mare parte din textele culese în timpul expedițiilor dialectologice prezintă interes etnografic și etnolingvistic. Este vorba de textele „tematice” sau etnotexte, ce descriu fie activități specifice mediului rural: construirea casei, spălatul tradițional al rufelor, cultivarea grâului, a porumbului, a florii-soarelui, muncile agricole (arat, secerat, treierat), lucrul la vie, îndeletniciri tradiționale, unele pe cale de dispariție (oieritul, albinăritul, pescuitul, tâmplăria, fierăria, cultivarea și prelucrarea cânepii, prelucrarea lânii și țesutul), tăiatul porcului, prepararea unor alimente de bază (pâine, brânză) și a bucatelor tradiționale (mămăligă, sarmale, plăcinte, cozonac, preparate din carne de porc), producerea vinului și a rachiului; fie/sau unele credințe populare, practici culturale, tradiții și obiceiuri: obiceiuri la naștere, la botez, la nuntă și la înmormântare, la diferite sărbători (Crăciun, Anul Nou, Paște, Ispas, Duminica Mare, Sânziene, Sfântul Andrei), obiceiuri sociale (claca, șezătoarea, hora), ritualuri și practici magice (Paparuda, Caloianul, descântatul, vrăjitul), ființe fantastice (Zburătorul, Strigoaica, Vârcolacul, Fata pădurii), portul popular, punând în lumină aspecte esențiale ale vieții țăranului român și ale patrimoniului cultural românesc. Pentru o mai bună cunoaștere a elementelor culturii materiale, autorii unor volume de texte publică în secțiunea „Ilustrații” fotografii, reprezentând elemente ale habitatului rural tradițional, obiecte și unelte din gospodăria țărănească (a se vedea, de exemplu, volumele din seria TD-Mold. Bucov.).

Valorificarea bogatelor informații de natură etnografică rămâne a fi, însă, un deziderat pentru domeniul cercetării. Făcând o evaluare a utilizării textelor dialectale, reputatul dialectolog ieșean Stelian Dumistrăcel constată cu surprindere și cu regret că acestea „nu au fost încă puse la contribuție pentru 
analize etnolingvistice extinse”, deși interesul pentru ,investigarea etnolingvistică a mediului rural”, „mărturisit în termeni expliciți” în prefețele volumelor apărute până în prezent, pe lângă interesul lingvistic - primordial, constituie una din principalele motivații ale înregistrărilor de teren și un criteriu de bază în selectarea textelor pentru publicare, fapt confirmat și de ponderea etnotextelor în cadrul corpusurilor. Există mai multe studii de valoare referitoare la diverse terminologii populare, dar acestea sunt elaborate, de regulă, exclusiv în baza datelor din atlasele lingvistice, fără a se recurge la textele dialectale, care, fiind corelate, în mare parte, cu tematica întrebărilor din chestionar, „cuprind infinit mai multe informații față de prezența cuvintelor notate pe hărți” (Dumistrăcel, 2014, p. 127-130).

Din categoria etnotextelor fac parte și texte folclorice: povești, cântece lirice, cântece rituale, orații de nuntă, ghicitori, descântece, urături etc., unele prezentate separat, altele incluse în descrieri de obiceiuri și practici magice. Prezența lor în corpusurile de texte dialectale se explică prin relația strânsă și îndelungată ce există între dialectologie și folcloristică, ca domenii preocupate de cultura orală. „Textele respective, susţine V. Frățilă, pot fi studiate atât din punct de vedere lingvistic, cât și din punct de vedere folcloric: dialectologul va studia forma textului, iar folcloristul fondul acestuia" (apud Mărgărit, 2012, p. 258). Prin urmare, chiar dacă nu s-a urmărit neapărat completarea culegerilor de folclor, creațiile literare populare culese în timpul anchetelor dialectale pot constitui obiectul unor cercetări folcloristice.

Atât etnotextele, prin descrierea elementelor de civilizație și cultură tradițională populară, cât și așa-numitele sociotexte, prin evocarea faptelor păstrate vii în memoria colectivă, sunt de mare utilitate pentru cercetările istorice. De altfel, înșiși autorii lucrării Graiul nostru, o primă culegere de texte „din toate părțile locuite de Români”, le considerau „documente sufletești, culturale și, în parte, istorice" (GN, 1906, p. XIV). În texte își găsesc reflectare o serie de probleme ce le confirmă valoarea de documente istorice: condițiile de trai ale țăranilor români, istoria/ legenda unor sate concrete, evenimentele ce au marcat viața poporului român, în special de-a lungul secolului trecut (războaie, schimbări politice, tulburări sociale, foamete, deportări, colectivizare etc.), cauzele și condițiile stabilirii românilor în zone mai mult sau mai puțin îndepărtate de arealul românesc, procesul deznaționalizării (programate) a etnicilor români din arii izolate, dar și din ariile periferice, aflate, în virtutea împrejurărilor istorice, în afara granițelor României, măsura în care românii din medii de altă origine și-au păstrat obiceiurile, tradițiile, creațiile folclorice 
și portul popular ca mărci ale identității lor etnice etc.

Interesului istoric i se asociază, de cele mai dese ori, cel sociologic sau cel sociolingvistic.

În aria preocupărilor sociologice se înscriu diverse aspecte ale vieții sociale pe care le dezvăluie o analiză, fie și sumară, a textelor dialectale: relațiile între membrii comunităților rurale românești, obiceiurile, atitudinile, modelele de gândire care le sunt specifice, valorile morale care le ghidează comportamentul, cataclismele sociale pe care le-au cunoscut etc.

Problemele de ordin sociolingvistic se desprind atât din conținutul textelor, cât și din particularitățile de grai pe care le fixează. Întrucât surprind graiurile la un anumit stadiu de evoluție, textele permit studierea schimbărilor survenite ca urmare a influenței limbii literare prin intermediul școlii, administrației, armatei, mijloacelor de comunicare în masă, stabilirea direcției dezvoltării lor, determinarea caracterului lor novator sau arhaic - probleme ce țin atât de domeniul sociolingvisticii, cât și de cel al dialectologiei și al istoriei limbii. Dată fiind diversitatea subiecților anchetați, textele sunt concludente în privința variației sociale a graiurilor în funcție de vârsta, sexul, nivelul de cultură al informatorilor (a se vedea, în acest sens, Cazacu, 1976). În cazul comunităților din medii aloglote, vorbirea informatorilor indică gradul de cunoaștere a idiomului matern, modificările datorate contactului cu alte limbi, dar mai ales presiunii exercitate de limbile oficiale. Reproducem, pentru exemplificare, câteva fragmente din textele culese în ultimul deceniu al secolului trecut în enclaveleromânești din sud-estul Ucrainei și din sudul Federației Ruse:

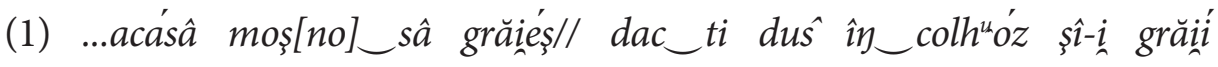

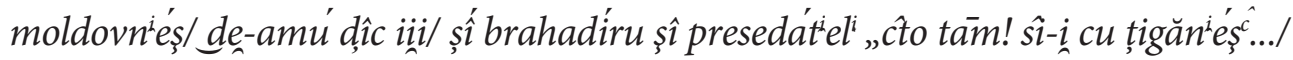
nu țîháscom inazicóm razîváiente e?/ da/ cu límba țîgănẹáscâ? nú! grăiț aculié acásă móşno să grăiț da acul'é nu grăiț’"// (Marin et. al., 2016, p. 321)

(2) [În sat mai vorbiți şi cu alţi oameni moldoveneşte?]

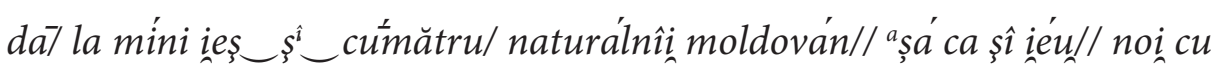
dîns grăíím moldovenéşç wot//(Marin et. al., 2016, p. 322)

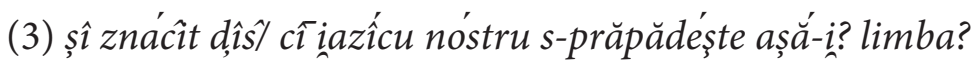

[Apoi, cam spre asta merge.]

îspre-aiásta? așắ-i ?

[da.]

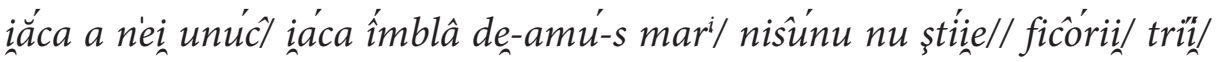




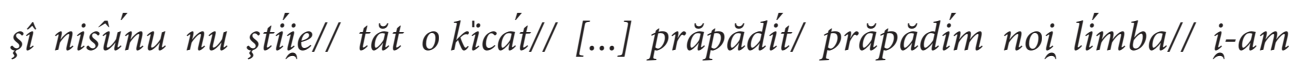
audî́t/ i-am audî́t în rádio a spúni câ trébâ vo/ vo/ [k]/ vozrazdit'/

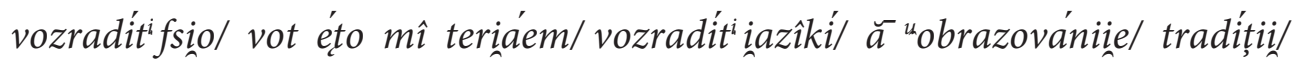
fsio// [...]// znácitt/ noi prăpădim/prăpădím//(Marin et. al., 2016, p. 537)

Mostre, precum cele prezentate mai sus, ilustrează cu prisosință situația precară a graiurilor moldovenești supuse asimilării progresive într-un mediu ostil, dominat de ideea superiorității limbii oficiale, consecințele bilingvismului/ diglosiei (interferențe, împrumuturi, alternanța și amestecul a două coduri: grai matern - limbă oficială etc.) ce denotă „o degradare progresivă a mecanismelor de autoorganizare și autoreglare" (Pavel, 2003, p. 89), prefigurând dispariția iminentă a limbii române în spațiul est-slav, prin substituirea ei cu limba majoritară (rusă sau ucraineană), în condiţiile izolării complete de arealul românesc, ale lipsei oricărui contact cu limba română (literară), ale restrângerii sferei de utilizare a idiomului matern și abandonării lui de generațiile tinere. Fenomenele menționate pot fi abordate atât din perspectivă sociolingvistică, cât și din perspectiva altor discipline, lingvistice, precum istoria limbii, dialectologia istorică, lingvistica generală, sau nelingvistice, cum ar fi psihologia și sociologia, care se interesează de bilingvism ca tip de comportament, respectiv, de corelația dintre prestigiul idiomurilor utilizate în cadrul unei comunități și statul social al membrilor acesteia, de situația social-politică în care se produce contactul dintre limbi (Moldovan, 2005).

Ca surse pentru cercetările din domeniul psihologiei, textele dialectale pot servi drept bază pentru a formula judecăți asupra comportamentului vorbitorilor, în general, a comportamentului lor verbal, în special, și a depista cauzele care le generează, determinările din mediul social, dat fiind că în vorbirea informatorilor apar elemente, care, pe de o parte, le trădează profilul psihologic, pe de altă parte, reflectă influența ambianței, a contextului general în care se află, a relației pe care au stabilit-o cu anchetatorul.

Impactul contextului social-istoric şi situaţional asupra modului cum se concretizează limba în discurs constituie obiectul psiholingvisticii (în concepția Tatianei Slama-Cazacu), care, pentru a-l discerne, trebuie să urmărească fenomenul comunicării în desfăşurarea lui în situații reale, concrete. Mostrele de limbă română vorbită, fie și la nivel dialectal, pot constitui suportul empiric necesar acestui domeniu interdisciplinar, apărut la granița dintre psihologie și lingvistică, pentru a-şi atinge scopul: acela de a „dezvălui cu adevărat as- 
pectele comunicării umane așa cum este în realitate și chiar unele fenomene ale limbii în funcțiune (care apar când limba este privită în comunicare și în legătură cu psihicul uman, iar acesta în contextul social, începând cu relația dintre emițător și receptor)" (Slama-Cazacu, 1981, p. 329-330). Culegerea faptelor de limbă în cadrul unor ansambluri discursive, prin contactul direct cu informatorul, precum și utilizarea în calitate de material de cercetare a textelor înregistrate „pe viu” sunt puncte de contact ale dialectologiei cu psiholingvistica (Idem, 1968).

În afară de faptul că textele relevă starea psihică a vorbitorilor - factor ce determină selectarea anumitor mijloace de expresie din ansamblul de forme stocate în memorie, economia sau, din contra, bogăția și varietatea mijloacelor utilizate pentru a reda anumite experiențe personale sau aspecte ale vieții, momentele de ezitare, alternanța și amestecul de coduri etc., volumele publicate conțin, de obicei, observații, note sau comentarii mai desfășurate de natură psiholingvistică. Culegătorii textelor reunite în lucrarea Graiul nostru remarcau neîncrederea cu care „e privit cineva când îl întreabă pe țăran cum trăiește, ce crede despre cutare împrejurări” și lipsa de „voiciune și legătură” când e vorba să povestească ce i s-a întâmplat sau ce a auzit de la alții referitor la unele evenimente istorice (GN, 1906, p. VI). Remarci cu privire la predispozițiile comunicative ale interlocutorilor săi făcuse și Emil Petrovici: „În unele localități anchetate, printre informatori s’au găsit buni povestitori dela care am putut aduna texte mai lungi și mai interesante...; în alte părți, subiecții anchetați, excelenți când trebuia să dea informații precise și demne de încredere, dar scurte, despre industria casnică, agricultură, păstorit, etc. și în general despre graiul pe care îl vorbesc, erau foarte sgârciți la vorbă și de un laconism supărător când li se cerea să povestească ceva mai pe îndelete" (Petrovici, 1943, p. VI).

Conștienți de influența exercitată asupra exprimării de către personalitatea celui care vorbește, de importanța particularităților de vârstă și de experiență socială, a factorilor intelectuali și afectivi, dialectologii români care au cules texte în cadrul proiectelor AFLR și NALR au notat și scurte caracterizări ale informatorilor, precizându-le vârsta, nivelul de instruire, ocupația, situația familială sau alte date biografice relevante pentru corecta receptare a mesajelor verbale, precum și unele mențiuni privind comportamentul subiecților „în situația de comunicare specială” care este ancheta. Cităm, cu titlu de exemplu, prezentările a două informatoare din localitatea Pungești, jud. Vaslui, din ale căror înregistrări pe bandă de magnetofon au fost selectate texte pentru 
volumul II din seria Texte dialectale a NALR. Moldova și Bucovina: „Geantă Elena [V c], 39 de ani; 4 clase. Are o fiică, de 19 ani, elevă la liceu. Volubilă, cu o personalitate accentuată și cu talent narativ cert, povestește colorat, dinamic, dramatizând narațiunea cu umor, prin dialog, inflexiuni ale vocii, mimică și gesticulaţie. Excelentă reprezentantă a graiului local (mai ales sub aspect fonetic)... Ciubotaru Maria, având porecla Braharu, [III a], 17 ani; 8 clase; agricultoare. Deplasări de scurtă durată la Bacău. Binevoitoare, dar marcată de condițiile de anchetă. Efortul de a se exprima „îngrijit” în faţa microfonului este evident prin apelul, frecvent, la fonetismele limbii literare, ca și prin apariția unor construcții sintactice nefirești; expuneri destul de schematice, succinte" (TD-Mold.Bucov. II/1, p. 51). Observațiile psiholingvistice ale anchetatorului sunt susținute de relatările celor două țărance, mai exact, de ansamblul elementelor verbale, paraverbale și nonverbale care le constituie (Ibidem, p. 98-100).

Se pare că tradiția de a însoți corpusurile de texte publicate cu remarci preliminare a fost inaugurată de Dumitru Șandru. Discipol și colaborator al lui Ovid Densusianu și Dimitrie Gusti, Dumitru Șandru a fost adeptul abordărilor interdisciplinare în cercetare care ,îmbină punctele de vedere ale diferitelor științe într-un punct de vedere unitar și sintetic”, urmărind „legăturile fenomenului pe care îl studiază cu întregul din care face parte”, după cum sublinia unul din mentorii săi (Gusti, 1940, p. 20). Drept mărturie stau amplele introduceri la colecțiile de texte dialectale, culese în perioada interbelică în diferite regiuni ale României și publicate în „Bulletin linguistique" (Șandru, 1933-1939), cuprinzând informații de ordin geografic, demografic, istoric cu privire la localităţile anchetate, explicații referitoare la desfășurarea anchetei, analiza amănunțită a particularităților dialectale depistate, precum și scurte descrieri ale informatorilor, în care datele sociolingvistice se împletesc cu fine observații de natură psiholingvistică: „Vasile Tulbure, zis Creangă, din Nisporeni, 70 de ani; nu știe carte; știe puțină rusă. A vorbit cu plăcere în fața fonografului, de parcă s-ar fi adresat persoanelor din anturajul său” [traducerea din limba franceză ne aparține] (Idem, 1933, p. 91). Modul de înregistrare a faptelor de limbă ,împreună cu întreaga situație reală în care sunt observate" este în deplin acord cu principiile metodologice ale psiholingvisticii (Slama-Cazacu, 1965, p. 141) și totodată avantajos pentru studierea limbii vorbite.

Așadar, prin valoarea sa documentară, textul dialectal reprezintă o importantă sursă de informații atât pentru lingviști, cât și pentru etnografi, 
folcloriști, istorici, sociologi, psihologi, pentru specialiștii din domeniile de graniță: etnolingvistica, sociolingvistica, psiholingvistica. Am punctat câteva dintre multiplele valențe ale textului dialectal, unele din ele chiar nebănuite.

\section{Referințe bibliografice:}

1 ARVINTE, Vasile. Contribuția lui Gustav Weigand la dezvoltarea dialectologieiromânești. În: Anuar de lingvistică și istorie literară, 1992-1993, XXXIII, A. Lingvistică, p. 29-42 [online]. Disponibil: http://www.alil.academiaromana-is.ro/wp-content/uploads/2012/08/ VASILE-ARVINTE-Contribu\%C5\%A3ia-lui-Gustav-Weigand-la-dezvoltareadialectologiei-rom\%C3\%A2ne\%C5\%9Fti.pdf[citat 20.04.2021]

2 BELTECHI, Eugen. [Recenzie la] Texte dialectale. Muntenia. I. În: Limba română, XXIII, București, 1974, nr. 5, p. 460-462.

3 BRÂNCUȘ, Grigore. [Recenzie la] Texte dialectale. Oltenia. În: Limba română, XVIII, București, 1969, nr. 2, p. 185-186.

4 CAZACU, Boris. Aspecte ale variației lingvistice în graiurile muntenești (pe baza datelor din „Texte dialectale. Muntenia”. I-III). În: Studii și cercetări lingvistice, XXVII, 1976, nr. 3, p. 293-299.

5 COHUȚ, Cornelia, VULPE, Magdalena. Graiul din zona „Porțile de Fier”. I. Texte. Sintaxă. București: Editura Academiei, 1973.

6 COLCIAR, Rozalia. Textul dialectal din perspectivă pragmatică. În: The Proceedings of the „European Integration - Between Tradition and Modernity” Congress, 2. Târgu-Mureș: Editura Universității „Petru Maior”, 2007, p. 232-238 [online]. Disponibil: https://www. diacronia.ro/en/indexing/details/A23724/pdf [citat 05.06.2021]

7 DUMISTRĂCEL, Stelian. Cuvânt înainte: Probleme ale publicării și ipostaze ale utilizării textelor dialectale ca instrument de cercetare. În: Noul Atlas lingvistic român, pe regiuni. Moldova și Bucovina. Texte dialectale, vol. I, partea 1. Iași: Editura Academiei Române, 1993, p. VII-XXXI.

8 DUMISTRĂCEL, Stelian. Prefaţă: Texte dialectale, texte orale, etno- şi sociotexte. În: Noul Atlas lingvistic român, pe regiuni. Moldova şi Bucovina. Texte dialectale, vol. II, partea 1. Bucureşti: Editura Academiei Române, 2003, p. 9-14.

9 DUMISTRĂCEL, Stelian. Textele orale în registru dialectal ca bază de date pentru exegeze lingvistice. În: Ion Coteanu - In memoriam. București: Editura Universităţii din București, 2014, p. 119-136 [online]. Disponibil: http://www.diacronia.ro/ro/indexing/details/V135 [citat 03.03.2021]

10 FAICIUC, Ion. [Recenzie la] Texte dialectale. Muntenia. I. În: Cercetări de lingvistică, 1974, nr. 1, p. 142-146.

11 GN, 1906 = Graiul nostru. Texte din toate părțile locuite de români, publicate de I.-A. Candrea, Ov. Densusianu, Th. D. Sperantia. Vol. I. Bucureşti: Atelierele grafice SOCEC \& Co., 1906.

12 GOT, Miorița. Stilistica limbii române. Bucureşti: Editura Fundației „România de Mâine”, 2007 [online]. http://www.colegiumaniucarei.ro/ckfinder/userfiles/files/STILISTICA\%20 LIMBII\%20ROMANE\%20-\%20M_Got.pdf[citat 29.05.2021]

13 GUSTI, Dimitrie. Un sistem de cercetări sociologice la teren. În: Indrumări pentru monografiile sociologice. Bucureşti: Institutul de Ştiințe Sociale al României, 1940, p. 3-21 [online]. https://monoskop.org/images/9/9f/Gusti_Dimitrie_Herseni_ Traian_\%C3\%8Endrum\%C4\%83ri_pentru_monografiile_sociologice_1940.pdf[citat 01.04.2021]

14 HREAPCĂ, Doina. Anchetele pentru culegerea textelor dialectale. Aspecte metodologice. 
În: Limba română, XXIV, Bucureşti, 1975, nr. 2, p. 137-144.

15 MARIN, Maria. Despe un arhaism morfologic specific graiurilor dacoromâne sudice. În: Anuar de lingvistică şi istorie literară, 2017, LVII, p. 249-256 [online]. http://alil. academiaromana-is.ro/wp-content/uploads/2019/03/MARIA-MARIN-Despre-unarhaism-morfologic-specific-graiurilor-dacorom\%C3\%A2ne-sudice.pdf[citat 03.02.2021]

16 MARIN, Maria, MĂRGĂRIT, Iulia, NEAGOE, Victorela, PAVEL, Vasile. Graiuri româneşti din Basarabia, Transnistria, nordul Bucovinei şi nordul Maramureşului. Texte dialectale şi glosar. București: „Bucureştii Noi”, 2000.

17 MARIN, Maria, MĂRGĂRIT, Iulia, NEAGOE, Victorela, PAVEL, Vasile. Graiuri dacoromâne din sud-estul Ucrainei. Studiu lingvistic. Texte dialectale. Glosar. Bucureşti: Editura Academiei Române, 2016.

18 MĂRGĂRIT, Iulia. Dialectologia şi receptarea corectă a textului folcloric. În: Filologia modernă: realizări şi perspective în context european. Abordări interdisciplinare în cercetarea lingvistică şi literară (In memoriam acad. Silviu Berejan). Ediția a IV, Chişinău, 10-12 noiembrie 2010. Coordonatori: Viorica Răileanu, Nina Corcinschi. Chişinău, 2012, p. 258-267.

19 MOLDOVANU, Gheorghe. Bilingvism, diglosie, conflict lingvistic: o disociere utilă pentru analiza limbilor în contact. În: Limba română, Chişinău, 2005, nr. 11, p. 6-17.

20 MOLEA, Viorica. Oralitatea în textul publicistic actual românesc. Chişinău: Prut Internațional, 2016.

21 PAPAHAGI, Tache. Graiul şi folklorul Maramureşului. Bucureşti: Cultura Naţională, 1925.

22 PAVEL, Vasile. Reconsiderări privind situația graiurilor româneşti din Caucaz. În: Limba şi literatura română în spațiul etnocultural dacoromânesc şi în diaspora. Secțiunea Lingvistică: I. Limbă şi identitate. Iaşi: Editura Trinitas, 2003 [online]. http://www.philippide.ro/ limba\%20si\%20literatura\%202003/12_Pavel.pdf [citat 14.03.2021]

23 PETROVICI, Emil. Texte dialectale. Supliment la Atlasul lingvistic român II (ALRT II). Sibiu-Leipzig: Muzeul Limbii Române - Otto Harrassovitz, 1943.

24 POP, Sever. La dialectologie: aperçu historique et méthodes d'enquêtes linguistiques. Première partie: Dialectologie romane. Louvain: Imprimerie J. Duculot Gembloux, 1950.

25 PURICE, Mihail, ZAGAEVSCHI, Vladimir, CIORNÎI, Ion. Curs de dialectologie română. Chișinău: „Lumina”, 1991.

26 PUȘCARIU, Sextil. Prefață. În: Atlasul lingvistic român, sub conducerea lui Sextil Pușcariu, partea I, vol. I: Părțile corpului omenesc şi boalele lui, de Sever Pop. Cluj: Muzeul Limbii Rpmâne, 1938, p. 7-14.

27 SALA, Marius. Câteva probleme de fonetică sintactică în „Texte dialectale” culese de E. Petrovici. În: Studii și cercetări lingvistice, VI, 1955, nr. 3-4, p. 223-238.

28 SLAMA-CAZACU, Tatiana. Metodologia psiholingvistică şi câteva dintre aplicațiile ei. În: Studii şi cercetări lingvistice, XVI, 1965, nr. 1, p. 131-147.

29 SLAMA-CAZACU, Tatiana. Psiholingvistica şi aplicarea metodei dinamic-contextuale în dialectologie. În: Studii şi cercetări lingvistice, XIX, 1968, nr. 2, p. 83-95.

30 SLAMA-CAZACU, Tatiana. Despre relațiile dintre lingvistică şi psihologie. În: Studii şi cercetări lingvistice, XXXII, 1981, nr. 4, p. 321-331.

31 ŞANDRU, Dumitru. Enquêtes linguistiques du Laboratoire de phonétique expérimentale de la Faculté des Lettres de Bucarest. În: Bulletin linguistique, I, 1933, p. 89-107; II, 1934, p. 201-237; III, 1935, p. 113-177; IV, 1936, p. 120-179; V, 1937, p. 125-189; VI, 1938, p. $173-230$

32 TD-Mold. = Texte dialectale. Supliment la Atlasul lingvistic moldovenesc (ALM), volumul I, partea 1, culese de V. Melnic, V. Stati, R. Udler, Chişinău: „Ştiința”, 1969; volumul I, partea 2, culese de V. Melnic, V. Stati, R. Udler, Chişinău: „Ştiința”, 1971; volumul II, 
partea 1, publicate de A. Dumbrăveanu, E. Constantinovici, sub redacția lui R. Udler, Chişinău: „Ştiința", 1971; volumul II, partea 2, publicate de A. Dumbrăveanu, sub redacția lui V. Stati, Chişinău: „Ştiința”, 1981; volumul III, partea 1, publicate de V. Corcimari, sub redacția lui R. Udler, Chişinău: „Ştiința”, 1981; volumul III, partea 2, publicate de A. Dumbrăveanu, sub redacția lui R. Udler, Chișinău: „Știința”, 1987.

33 TD-Mold.Bucov. = Noul Atlas lingvistic român, pe regiuni. Moldova şi Bucovina. Texte dialectale, vol. I, culese de Stelian Dumistrăcel şi publicate de Doina Hreapcă şi Ion-Horia Bîrleanu, Iaşi: Editura Academiei Române, partea 1, 1993, partea a 2-a, 1995, vol. II, partea 1, culese Ion-Horia Bîrleanu şi publicate de Doina Hreapcă şi Ion-Horia Bîrleanu, cu o prefață de Stelian Dumistrăcel, Bucureşti: Editura Academiei Române, 2002.

34 TD-Munt. I = Texte dialectale. Muntenia, vol. I, sub conducerea lui Boris Cazacu, de Galina Ghiculete, Paul Lăzărescu, Maria Marin, Bogdan Marinescu, Ruxandra Pană şi Magdalena Vulpe. București: Editura Academiei, 1973.

35 TD-Olt. = Texte dialectale. Oltenia, publicate sub redacția lui Boris Cazacu, de Cornelia Cohut, Galina Ghiculete, Maria Mărdărescu, Valeriu Şuteu şi Magdalena Vulpe. Bucureşti: Editura Academiei, 1967.

36 ȚIPLEA, Alexandru. Poezii populare din Maramureş. În: Maramureş, Țară veche. Antologie de folclor de pe Cursul Superior al Tisei alcătuită de Dumitru Iuga. BaiaMare: Editura Cybela, 2008, p. 179-252 [online]. https://fundatia-iuga.ro/Antologie_ Antologie170x240mm.pdf[citat 20.04.2021]

37 WEIGAND, Gustav. Samosh und Theissdialekte. În: „Sechster Jahresbericht des Instituts für rumänische Sprache (Rumänisches Seminar) zu Leipzig", 1899, p. 1-85 [online]. https:// archive.org/details/jahresberichtde01publgoog/page/n730/mode/2up [citat 23.04.2021]

38 WEIGAND, Gustav. Die Dialekte der Bukowina und Bessarabiens. Leipzig: Johann Ambrosius Bart, 1904 [online]. https://archive.org/details/diedialektederb00weiggoog [citat 23.04.2021]

Notă: Articolul a fost realizat în cadrul proiectului de cercetare 20.80009.1606.01 Valorificarea științifică a patrimoniului lingvistic național in contextul integrării europene, Institutul de Filologie Română „Bogdan Petriceicu-Hasdeu" al MEC. 